\title{
The structure of modern cultural theory
}

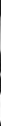
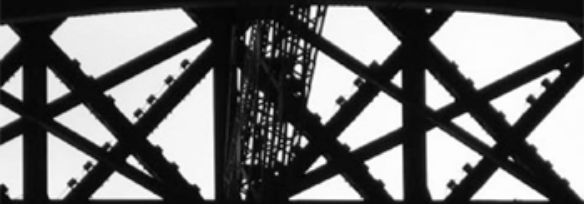

THOMAS OSBORNE 


\section{The structure of modern cultural theory}

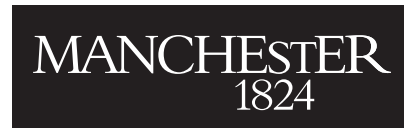

Manchester University Press 
Thomas Osborne - 9781847791849

Downloaded from manchesterhive.com at 04/26/2023 09:58:32AM 


\title{
The structure of modern cultural theory
}

\author{
Thomas Osborne
}

\author{
Manchester University Press \\ Manchester and New York
}

distributed exclusively in the USA by Palgrave Macmillan 
Copyright $\odot$ Thomas Osborne 2008

The right of Thomas Osborne to be identified as the author of this work has been asserted by him in accordance with the Copyright, Designs and Patents Act 1988.

\author{
Published by Manchester University Press \\ Oxford Road, Manchester M13 9NR, UK \\ and Room 400, 175 Fifth Avenue, New York, NY 10010, USA \\ www.manchesteruniversitypress.co.uk \\ Distributed exclusively in the USA by \\ Palgrave Macmillan, 175 Fifth Avenue, New York, \\ NY 10010, USA \\ Distributed exclusively in Canada by \\ UBC Press, University of British Columbia, 2029 West Mall, \\ Vancouver, BC, Canada V6T 1 Z2 \\ British Library Cataloguing-in-Publication Data \\ A catalogue record for this book is available from the British Library \\ Library of Congress Cataloging-in-Publication Data applied for
}

ISBN 9780719078231 hardback

First published 2008

$17161514131211100908 \quad 10987654321$

Typeset by

Action Publishing Technology Ltd, Gloucester

Printed in Great Britain

by CPI Antony Rowe Ltd, Chippenham, Wiltshire 